\title{
BirdPix - report on the photographic atlas of the birds of Nigeria, 2012-2019
}

\author{
Abubakar S. Ringim
}

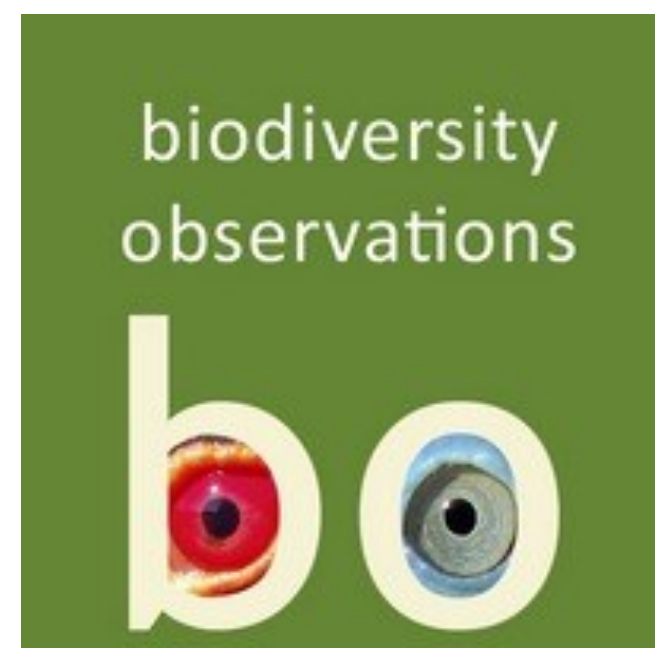

Ringim AS 2020. BirdPix - report on the photographic atlas of the birds of Nigeria, 2012-2019. Biodiversity Observations 11.4:1-10

Bird atlas, BirdPix, citizen science, Nigeiria 


\section{Ornithology}

\section{BirdPix - report on the photographic atlas of the birds of Nigeria, $2012-2019$}

\author{
Abubakar S. Ringim, Department of Biological Sciences, Federal \\ University Dutse, P.M.B. 7156, Dutse, Jigawa State, Nigeria
}

asringim@gmail.com

\section{Abstract}

This paper describes progress with the atlas of birds of Nigeria, from 7 March 2012 to 15 December 2019. The database of the project contained 658 records of 246 species submitted to the BirdPix section of the Virtual Museum. The BirdPix section of the Virtual Museum was launched in 2012 and is a supplementary data capture project for the African Bird Atlas. Over this period, for Nigeria, twelve citizen scientists contributed records to BirdPix. The most frequently recorded species were Laughing Dove Streptopelia senegalensis (769 records across its range, with 12 in Nigeria, from 12 grid cells), and Northern Red Bishop Euplectes franciscanus (30 records across the range, and recorded in 11 grid cells in Nigeria). At least two photographs of species range extensions had been submitted. This paper highlights the role of citizen science in biodiversity conservation and provides up-to-date information on the species distribution maps and lists of bird species recorded in the grid cells. Without a doubt, the BirdPix database will only be comprehensive if it contains the entire knowledge base of the species occurring within each grid cell. Data generated in the BirdPix project can be used for monitoring and modelling changes in species distributions over time. Increased awareness of the concept of citizen science and increased volunteer recruitment should be top priorities.

Keywords: Biodiversity mapping, Conservation, Public awareness, Species distribution

\section{What is BirdPix, and why does it matter?}

BirdPix is a photographic atlas of birds of Africa. It was launched in 2012. In Nigeria, the first record was uploaded into the BirdPix database on 7 March 2012, though historical records date back to 27 February 2007 (Figure 1). The goals of the project are (1) to assist with the mapping of the current distributions of birds occurring in Africa, and (2) to serve as a repository of photographic distribution records for this group (Loftie-Eaton et al. 2018). This ambitious project helps to provide up-to-date distribution maps for birds, important organisms within biodiversity research that serve as good indicators of environmental modification, and facilitates the prioritization of areas for biodiversity conservation (Donald et al. 2019).

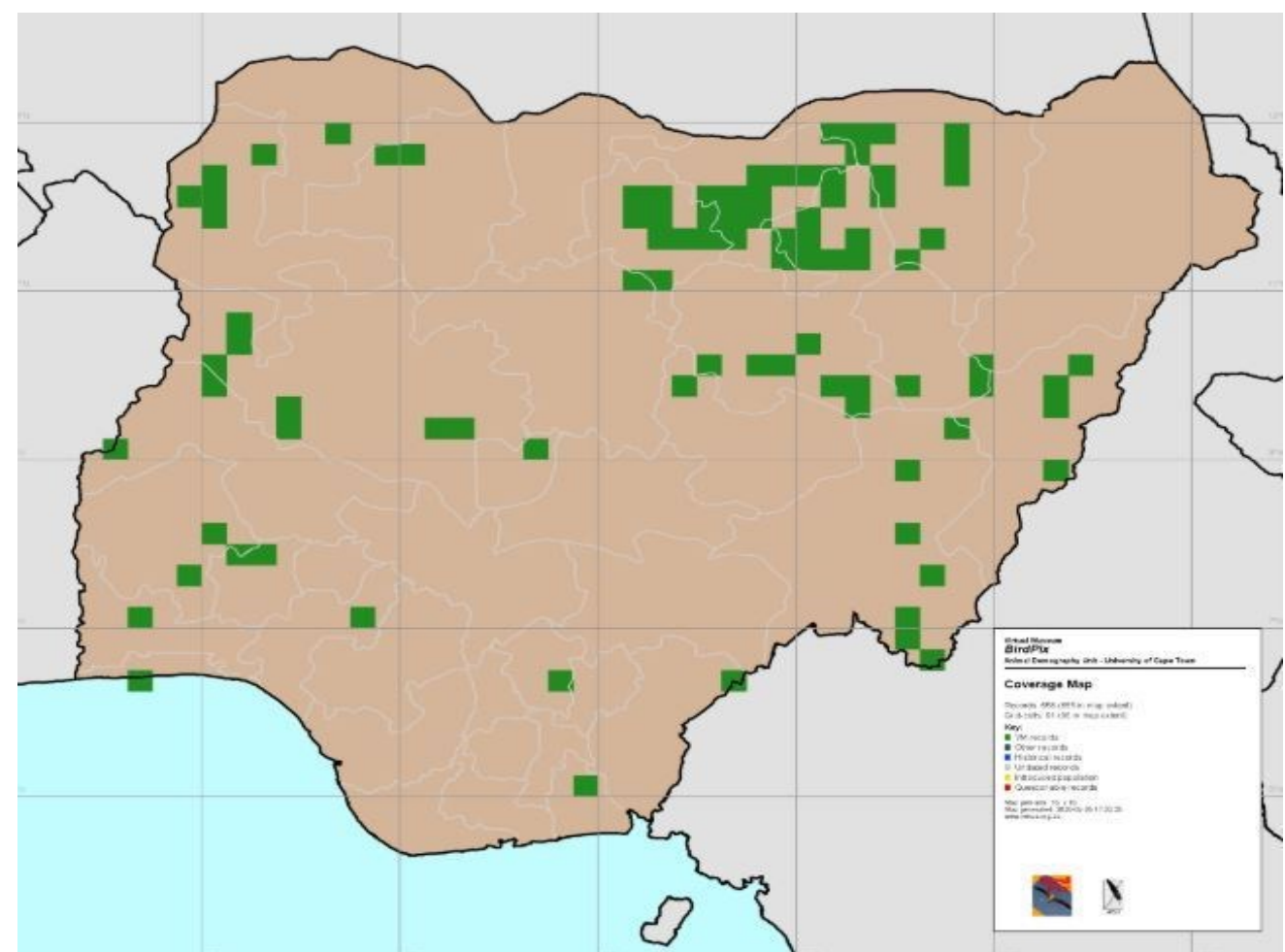

Figure 1. Distribution map of all BirdPix records in Nigeria, 2007-2019. Each green square is a quarter degree grid cell with at least one BirdPix record. 
BirdPix is an excellent place to deposit photos of species that are out- tific processes (Louv \& Fitzpatrick 2012). Through this concept, scienside of their normal ranges. For atlasers, it can be used to keep photos tists and the public share ecological knowledge, taxonomic skills and of species for which "Out of Range Forms" (ORFs) are generated. For awareness of biodiversity loss through collaborative research projects bird ringers, BirdPix can be used to store interesting photos of birds in at national, regional or geographic scales. These include, for example, the hand; for example, pictures showing unusual patterns of wing bird atlases, i.e. monitoring trends of bird populations, migration, etc.; moult, plumage variation with age and sex, etc. BirdPix is especially aquatic insect counts; sea turtle surveys; and reef fish surveys (Louv \& valuable as a source of incidental records for the formal Nigeria Bird Fitzpatrick 2012). This approach to biodiversity mapping (biomapping) Atlas Project (Tende et al. 2016) in that it enables people who are not has a long history dating back to the beginning of science and natuconfident of their bird identification skills to contribute to mapping distri- ral history observation, including the work of John Ray, the great 17 thbutions. Although the person uploading the photograph to BirdPix is century naturalist who involved many volunteers in specimen collection encouraged to provide identification, the expert panel for the project (Kobori et al. 2016).

tries to identify all records to species level.

Nevertheless, the concept of citizen science has only gained tremenNot only does BirdPix provide information about the current distribution dous attention in recent decades; in particular, due to increasing of birds, but the backgrounds to the photos also help reveal information threats to biological diversity and the need to map the distributional about the diversity of habitat types they depend on. Data from BirdPix patterns of species and ensure their conservation. Citizen scientists has the potential to influence policy and decision making on issues re- can generate huge datasets which have yielded important discoveries lated to biodiversity conservation, particularly for birds. In this paper, I and results such as tracking biological changes and the impacts of ensummarize the records of the BirdPix database for Nigeria submitted vironmental, anthropogenic and climatic phenomena on biodiversity over the period 7 March 2012 to 15 December 2019.

\section{BirdPix database}

This paper provides information related to BirdPix records of the birds of Nigeria as well as a distribution map. It makes use of the openaccess citizen science database developed and managed by the Animal Demography Unit (ADU), the University of Cape Town, South Africa (Fitzpatrick Institute of African Ornithology, available online as BirdPix at $h t t p: / / v m u s . a d u . o r g . z a /$ ?vm=BirdPix). This paper is based on species recorded in the quarter degree grid cells (QDGCs) in Nigeria

\section{What is citizen science?}

Citizen science is a concept which engages the public in a scientific project (Kobori et al., 2016), or otherwise involves public participation in some or all aspects of biodiversity and environmental assessments (Chandler et al. 2017). On one hand, citizen scientists are people who have chosen to use their free time and resources to engage in scien(Donnelly et al. 2014). Worldwide, a number of organizations are involved in citizen science movements, such as the National Wildlife Federation of the United States, the Woodland Trust in the United Kingdom, and Fitzpatrick Institute of African Ornithology, South Africa (Louv \& Fitzpatrick 2012). In Nigeria, the A.P. Leventis Ornithological Research Institute (APLORI) runs and promotes citizen science, with fewer than 200 volunteers as of June 2020 http:// nigeriabirdatlas.adu.org.za/coverage.php

\section{History of citizen science and biomapping in Nigeria}

The formal launch of the Nigeria Bird Atlas Project (NiBAP) in November 2015 largely marked the beginning of organized citizen science in Nigeria. NiBAP is an initiative of the APLORI, launched with technical support from the ADU, who successfully managed the Southern African Bird Atlas Project (SABAP) for over 10 years. With the primary aim of engaging citizen participation to update and map the distributions of birds in Nigeria, NiBAP started with a project team of just three individuals at its launch. However, participation has gradually grown since 
then to include over 190 individuals in June 2020 Table 2. The 30 most recorded species in Nigeria in the BirdPix database on 15 December 2019. http://nigeriabirdatlas.adu.org.za/coverage.php

The first column provides the BirdPix species codes and the final column the number of records.

Public awareness and participant engagement were mainly carried out via seminars and training workshops at Universities across the country. One such event, titled "Atlasing and monitoring in Africa" was conducted in November 2017, with APLORI collaborating with the ADU to host two days of meetings between managers, stakeholders and other key citizen scientists to discuss current and ongoing atlas and monitoring schemes based on the protocol developed by the ADU. During this meeting, Dr. Megan LoftieEaton delivered a presentation titled "The Virtual Museum (VM)" and introduced the idea of biomapping through nature photography, also highlighting the role of citizen scientists in biomapping through the VM project. These projects include BirdPix (distribution maps

Table 1. Bird observers who submitted records from $\mathrm{Ni}$ geria to the BirdPix database before 15 December 2019.

\begin{tabular}{|l|c|}
\hline Observer & Records \\
\hline Ringim, Abubakar S. & 476 \\
Dickson, Rob & 70 \\
Underhill, Les & 53 \\
Owolabi, Bibitayo A. & 36 \\
Cronje Pieter & 27 \\
Okafor, Chioma & 26 \\
Rodstrom, Gunilla & 6 \\
Talatu, Tende & 4 \\
Elstadt, Cobus & 4 \\
Adekola, Oluwadunsin & 3 \\
Braimoh, Bukola & 3 \\
Elisha, Emmanuel Barde & 1 \\
\hline
\end{tabular}

\begin{tabular}{|c|c|c|c|c|}
\hline Code & Family & Species & Common name & $\mathrm{n}$ \\
\hline 317 & Columbidae & $\begin{array}{l}\text { Streptopelia senega- } \\
\text { lensis }\end{array}$ & Laughing (Palm) Dove & 12 \\
\hline 3748 & Ploceidae & Euplectes franciscanus & Northern Red Bishop & 11 \\
\hline 846 & Viduidae & Vidua macroura & Pin-tailed Whydah & 9 \\
\hline 851 & Viduidae & Vidua chalybeata & Village Indigobird & 9 \\
\hline 3506 & Alaudidae & Galerida cristata & Crested Lark & 9 \\
\hline 129 & Accipitridae & Milvus aegyptius & Yellow-billed Kite & 8 \\
\hline 2032 & Glareolidae & Pluvianus aegyptius & Egyptian Plover (Crocodile-bird) & 8 \\
\hline 3974 & Estrildidae & Uraeginthus bengalus & Red-cheeked Cordon Bleu & 7 \\
\hline 161 & Accipitridae & Accipiter badius & Shikra (Little Banded Goshawk) & 7 \\
\hline 410 & Meropidae & Merops pusillus & Little Bee-eater & 7 \\
\hline 264 & Scolopacidae & Tringa glareola & Wood Sandpiper & 7 \\
\hline 1702 & Pycnonotidae & Crinifer piscator & Western Grey Plantain-eater & 7 \\
\hline 3972 & Ploceidae & Sporopipes frontalis & Speckle-fronted Weaver & 7 \\
\hline 1530 & Coraciidae & $\begin{array}{l}\text { Coracias abyssinica (C. } \\
\text { abyssinicus) }\end{array}$ & Abyssinian Roller & 7 \\
\hline 1031 & Charadriidae & Vanellus spinosus & Spur-winged Plover (Lapwing) & 7 \\
\hline 872 & Fringillidae & Emberiza tahapisi & Cinnamon-breasted (Rock) Bunting & 6 \\
\hline 3996 & Viduidae & Vidua orientalis & Northern (Sahel) Paradise-Whydah & 6 \\
\hline 3852 & Passeridae & Passer griseus & Northern Grey-headed Sparrow & 6 \\
\hline 163 & Accipitridae & Melierax metabates & Dark Chanting-Goshawk & 6 \\
\hline 11491 & Pycnonotidae & Pycnonotus barbatus & Common Bulbul & 6 \\
\hline 2274 & Laniidae & Corvinella corvina & Yellow-billed Shrike & 6 \\
\hline 797 & Ploceidae & Ploceus cucullatus & Village (Spotted-backed) Weaver & 6 \\
\hline 355 & Centropodidae & Centropus senegalensis & Senegal Coucal & 6 \\
\hline 311 & Columbidae & Columba guinea & Speckled (Rock) Pigeon & 6 \\
\hline 517 & Dicruridae & Dicrurus adsimilis & Fork-tailed Drongo & 6 \\
\hline 394 & Cerylidae & Ceryle rudis & Pied Kingfisher & 5 \\
\hline 4104 & Fringillidae & Serinus leucopygius & White-rumped Seedeater & 5 \\
\hline 424 & Bucerotidae & Tockus nasutus & African Grey Hornbill & 5 \\
\hline 1880 & Columbidae & Streptopelia vinacea & Vinaceous Dove & 5 \\
\hline 1660 & Psittacidae & Poicephalus senegalus & Senegal Parrot & 5 \\
\hline
\end{tabular}




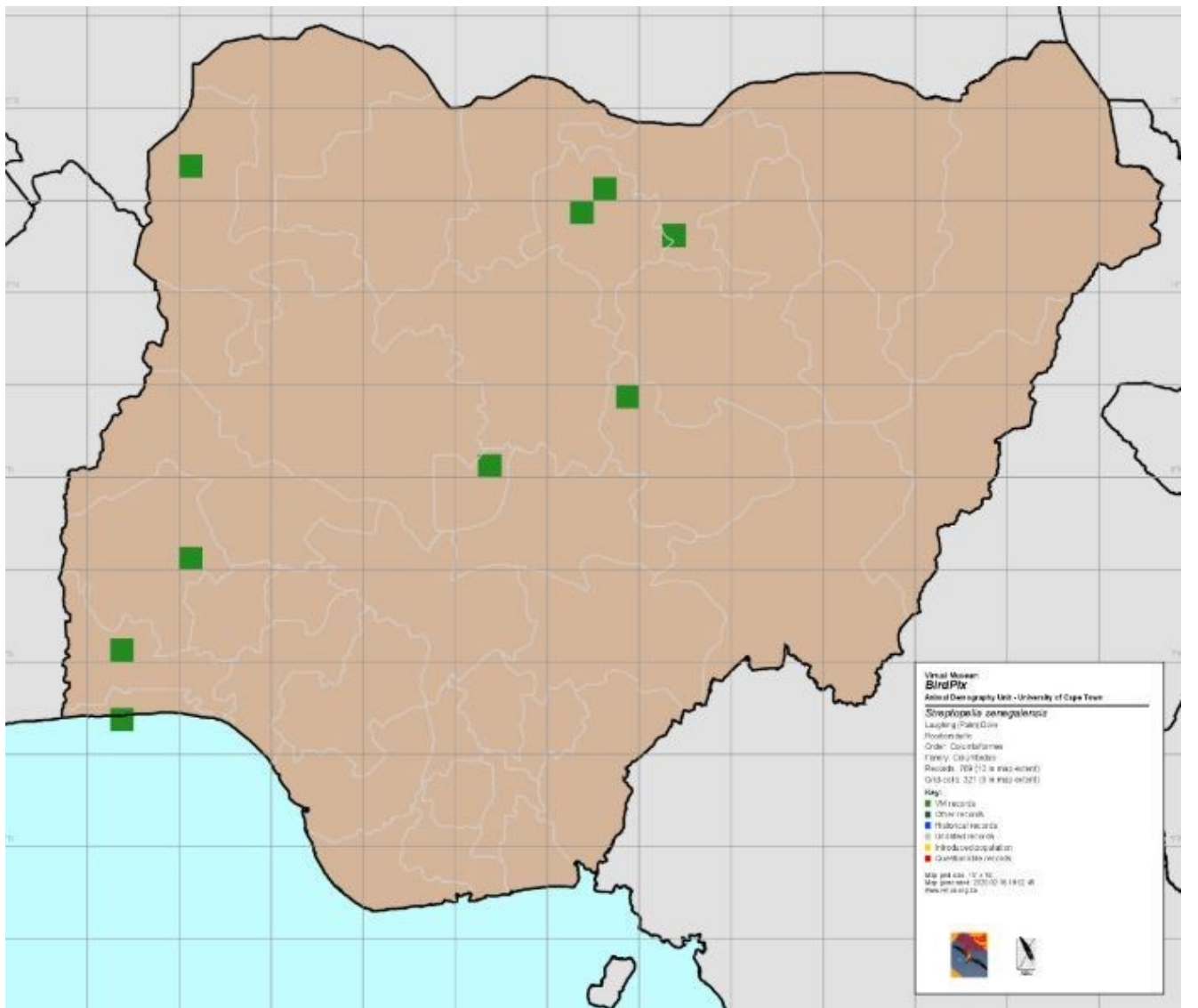

Figure 2. BirdPix distribution map for Streptopelia senegalensis in Nigeria .

for birds), FrogMAP (distribution maps for amphibians), LepiMAP (distribution maps for butterflies and moths), and ScorpionMAP (distribution maps for scorpions).

Through advocacy and creating continued awareness, participation in citizen science projects continues to grow in Nigeria. However, there appears to have been relatively greater engagement in NiBAP than in biomapping projects in Nigeria. By 15 December 2019 there were 12 contributors to the BirdPix project in Nigeria (Table 1). Concerted efforts to promote increased public engagement in biomapping via the VM project are therefore badly needed. The VM has enormous potential, considering the relatively low level of expertise required to partici-

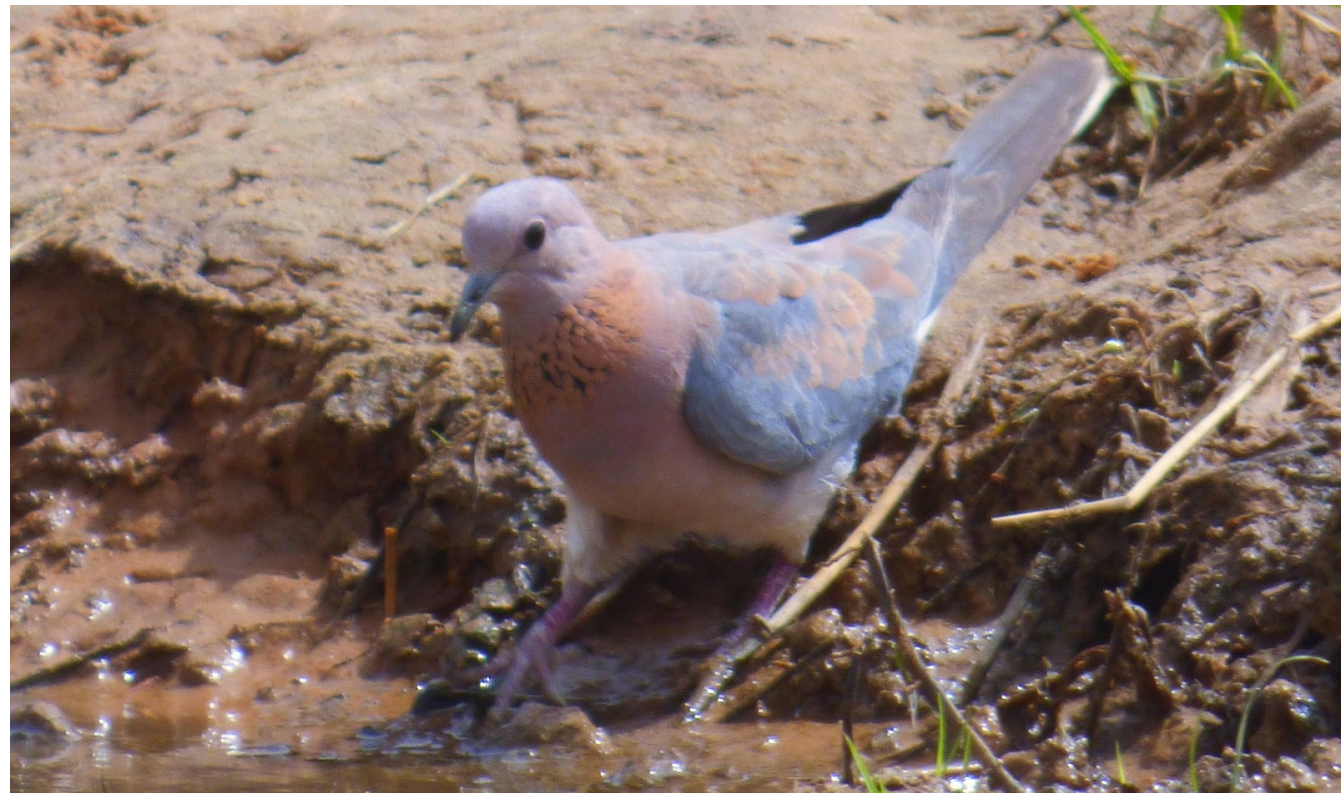

Figure 3. On 15 December 2019, there were 769 records of Streptopelia senegalensis in the BirdPix database across Africa. This Nigerian record is curated at http://vmus.adu.org.za/?vm=BirdPix-107132.

pate and the diversity of taxa represented, including reptiles, mushrooms, spiders, scorpions, dragonflies, etc.

\section{Is there a gap?}

Mapping the distributions of over 900 bird species in Nigeria (Dowsett 2018) within each QDGC is indeed a huge challenge. As Nigeria's biodiversity is predicted to plummet, largely due to increasing human population, urbanization, habitat loss, and pollution, mapping the distribution of birds is particularly urgent. A strong understanding of bird distributions will ensure the successful conservation of birds and other taxa, since birds are good umbrella species (Roberge et al. 2008).

\section{How many records were submitted to BirdPix?}

A total of 658 photographic records were submitted from Nigeria to the BirdPix database up to 15 December 2019. These included 246 spe- 
Ringim: BirdPix report for Nigeria

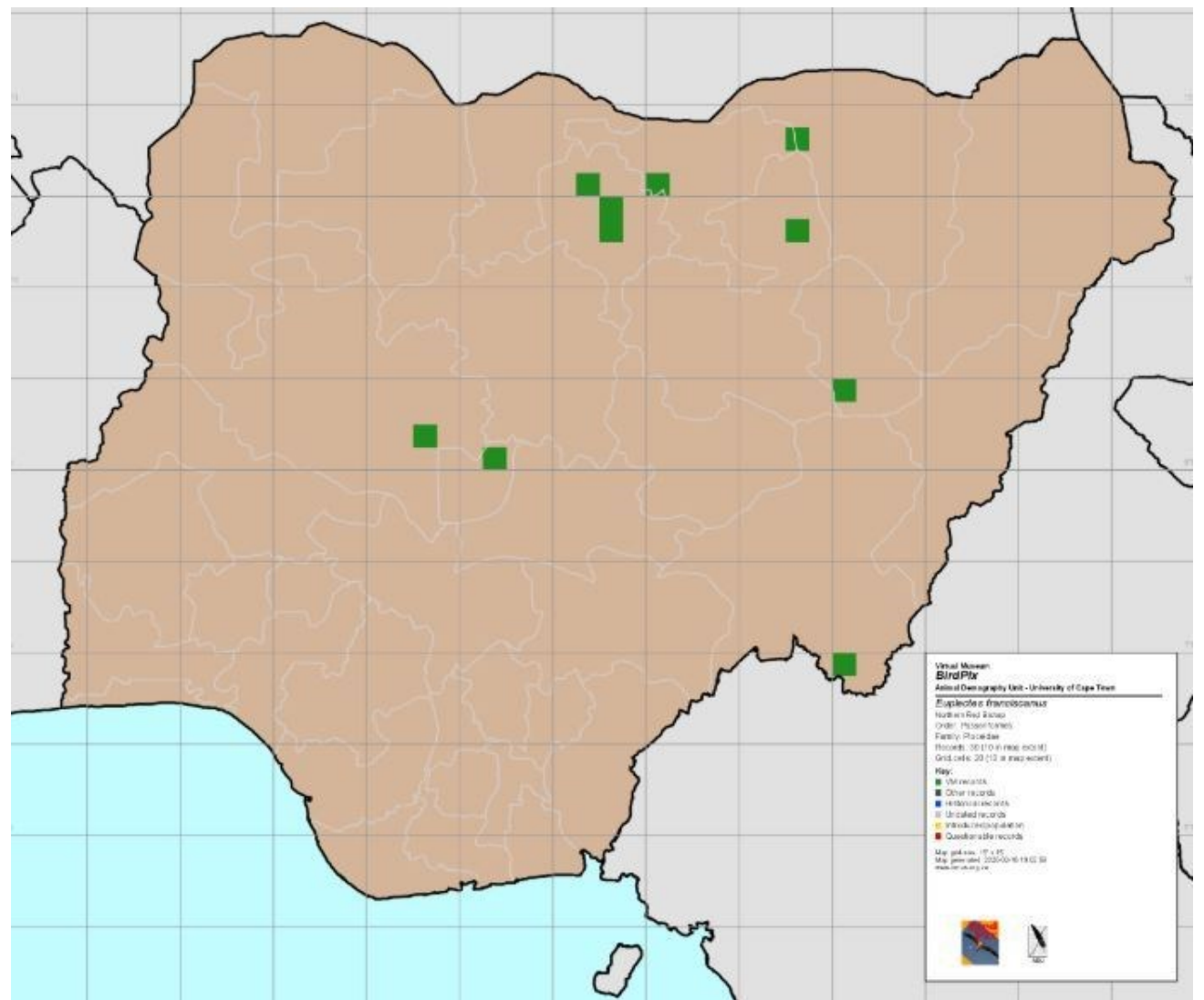

Figure 4. BirdPix distribution map for Euplectes franciscanus in Nigeria.

cies and were made in 90 quarter degree grid cells (Figure1). Thirty species have at least five BirdPix records (Table 2). The two most frequently recorded species were Laughing Dove Streptopelia senegalensis (recorded in 12 grid cells),(Figures 2 and 3) and Northern Red Bishop Euplectes franciscanus (11 grid cells) (Figures 4 and 5).

\section{Are there remarkable submissions in the BirdPix data- base from Nigeria?}

Since 2012, citizen scientists have made important but interesting submissions to the BirdPix project. Though every species is considered valuable, there are a few outstanding submissions which highlight the

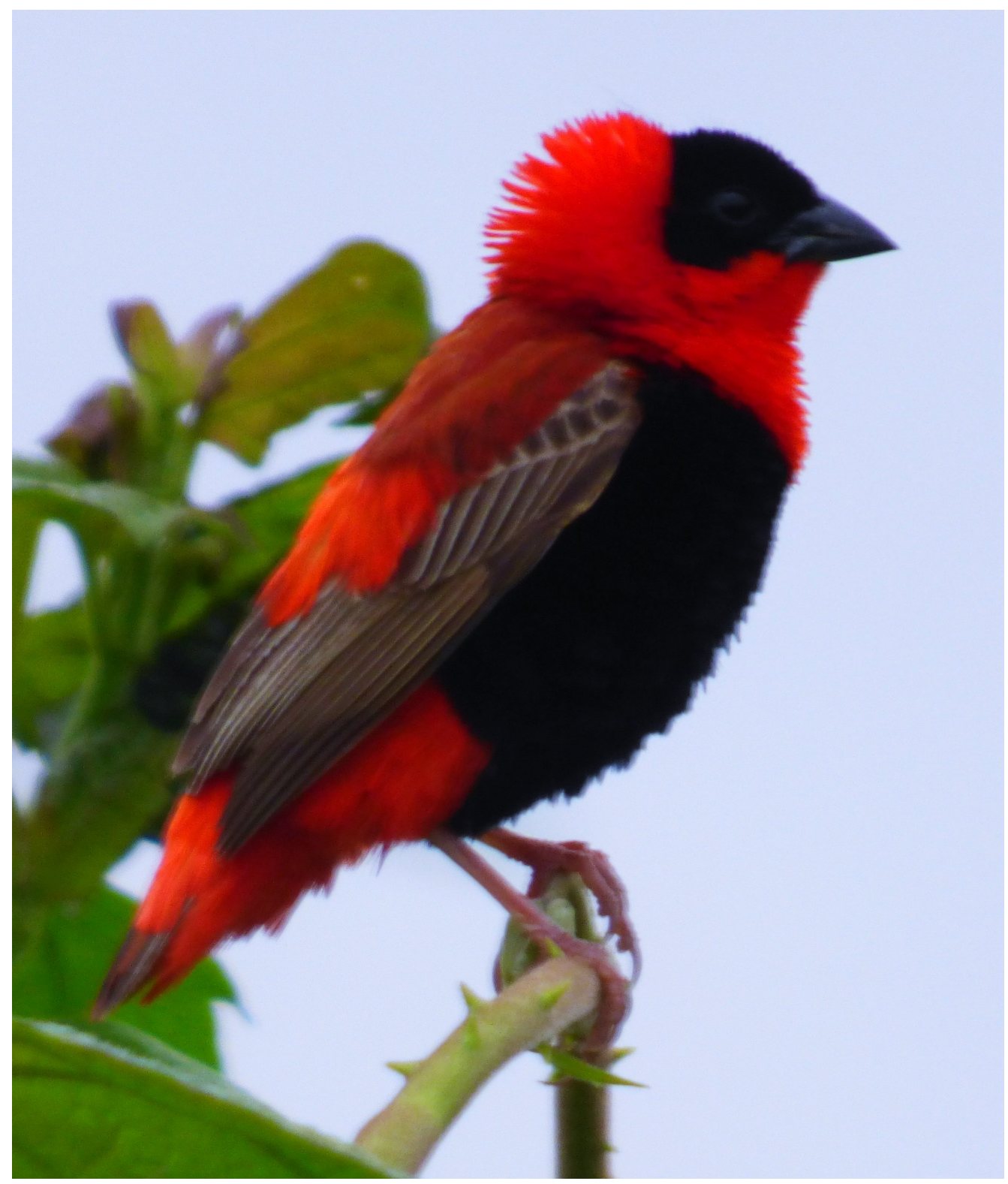

Figure 5. On 15 December 2019, there were 30 records of Euplectes franciscanus in the BirdPix database across western and eastern Africa, between Senegal and Ethiopia. This is one of the 11 Nigerian records in BirdPix, curated at $h$ ttp://vmus. adu.org.za/?vm=BirdPix-84550. 


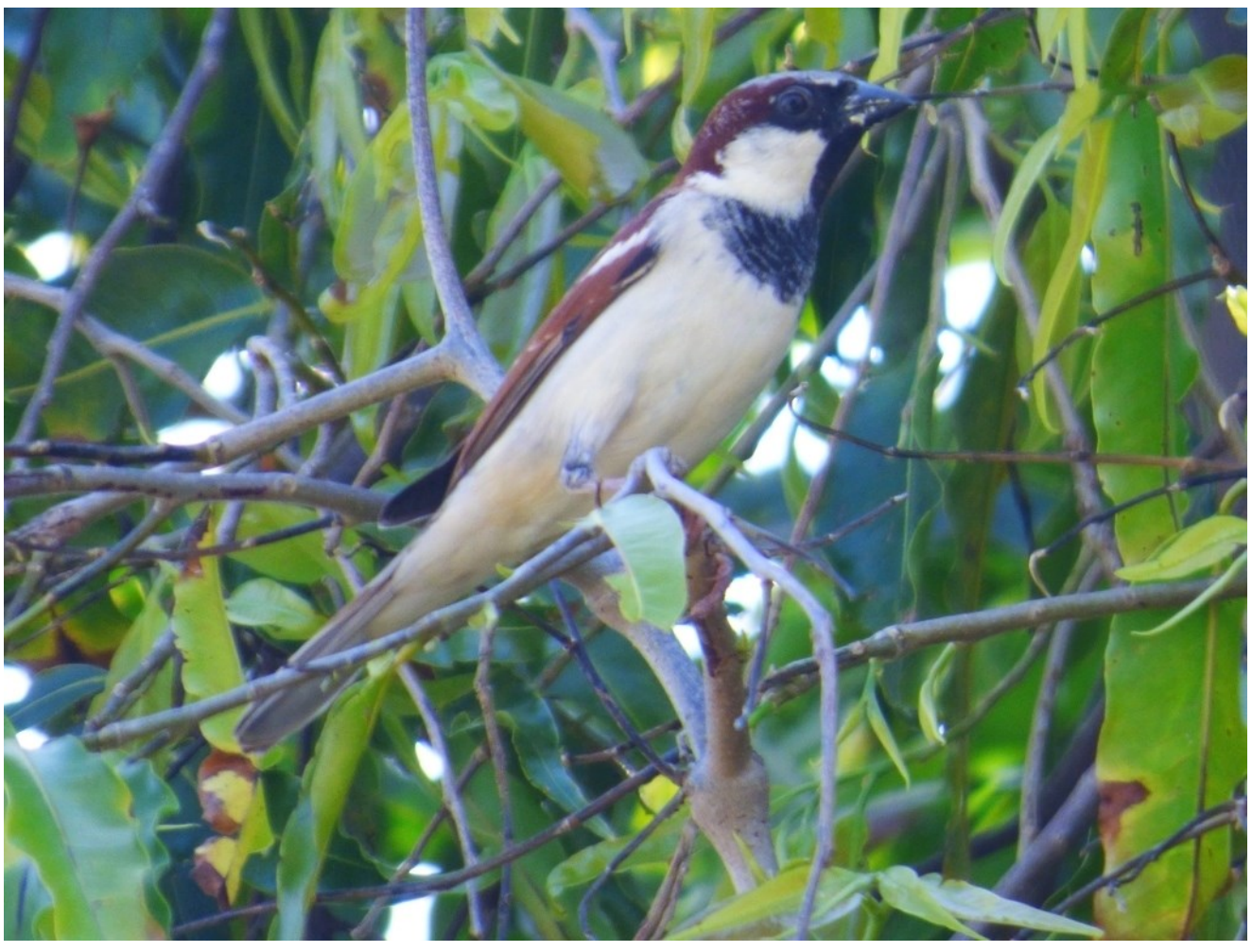

Figure 6. BirdPix record 107184, Passer domesticus from Potiskum, Yobe State, submitted by the author. It epresents a westward range expansion. Further details are at http://vmus.adu.org.za/?vm=BirdPix-107184

importance of citizen science. BirdPix No. 107184 is a record of House Sparrow Passer domesticus from Potiskum, Yobe State, on 4 October 2018 (http://vmus.adu.org.za/?vm=BirdPix-107184) (Figure 6). The second record of this species was from Azare, Bauchi State, on 1 February 2019 (curated at http://vmus.adu.org.za/?vm=BirdPix-71542). The distribution of the species was previously confined to the far northeastern corner of the country (Borrow \& Demey 2014). Wilson \& McGregor (2002) reported the first sighting of the species at Baga, Lake Chad, Borno State. These records (in Potiskum and Azare, respectively) indicate a westward range extension of the species (Ringim et al. 2019).

BirdPix No. 99229 is a record of Grey-backed Fiscal Lanius excubitoroides from Yola, Adamawa State, on 4 December 2019 (Figure 7).
This photographic record provides the first proof of the extension of the species' known range by $c$. $300 \mathrm{~km}$ south-westwards of its previously documented distribution in Nigeria (Ringim et al. 2020).

Photographic evidence of the occurrence of threatened species is of value to conservation managers. The BirdPix database contained 11 records of seven Red List species on 15 December (2019) (Table 3).

\section{How do I participate in the BirdPix project?}

In order to take part in the BirdPix project, you only need to take photos of birds and upload them to the BirdPix section of the Virtual Museum website at $h t t p: / / v m u s . a d u . o r g . z a /$. Do not worry if you cannot identify the photographed species, as an expert panel does this. Taking photographs of birds can be easy, as many species spend most of their time foraging or roosting. This provides the opportunity to take photographs at several angles. Moreover, many species occupy a specific niche, and will generally remain within the niche long enough to take several photographs from different angles.

Before uploading to the Virtual Museum, you need to register as a citizen scientist. The registration process is described here: https:// www.slideshare.net/Animal_Demography_Unit/how-to-register-as-acitizen-scientist-with-the-animal-demography-unit. Once registered, log on to the website using your email address and password. The "Data upload" section now becomes visible. The critical information that needs to be uploaded into the database is date, location, and a series of one to a maximum of three photographs of a single species, preferably different angles of the same individual. Guidance on the upload process is provided in this slideshow: https://www.slideshare.net/ Animal_Demography_Unit/how-to-submit-records-to-the-virtual-

\section{museums}

The expert panels and the most experienced citizen scientists will in most cases confirm species identifications within a week. Some records take longer, in part due to large numbers of submissions and the fact that for some photos, species-level identification is not possible (Underhill et al. 2018). Records are sometimes identified to genus or 


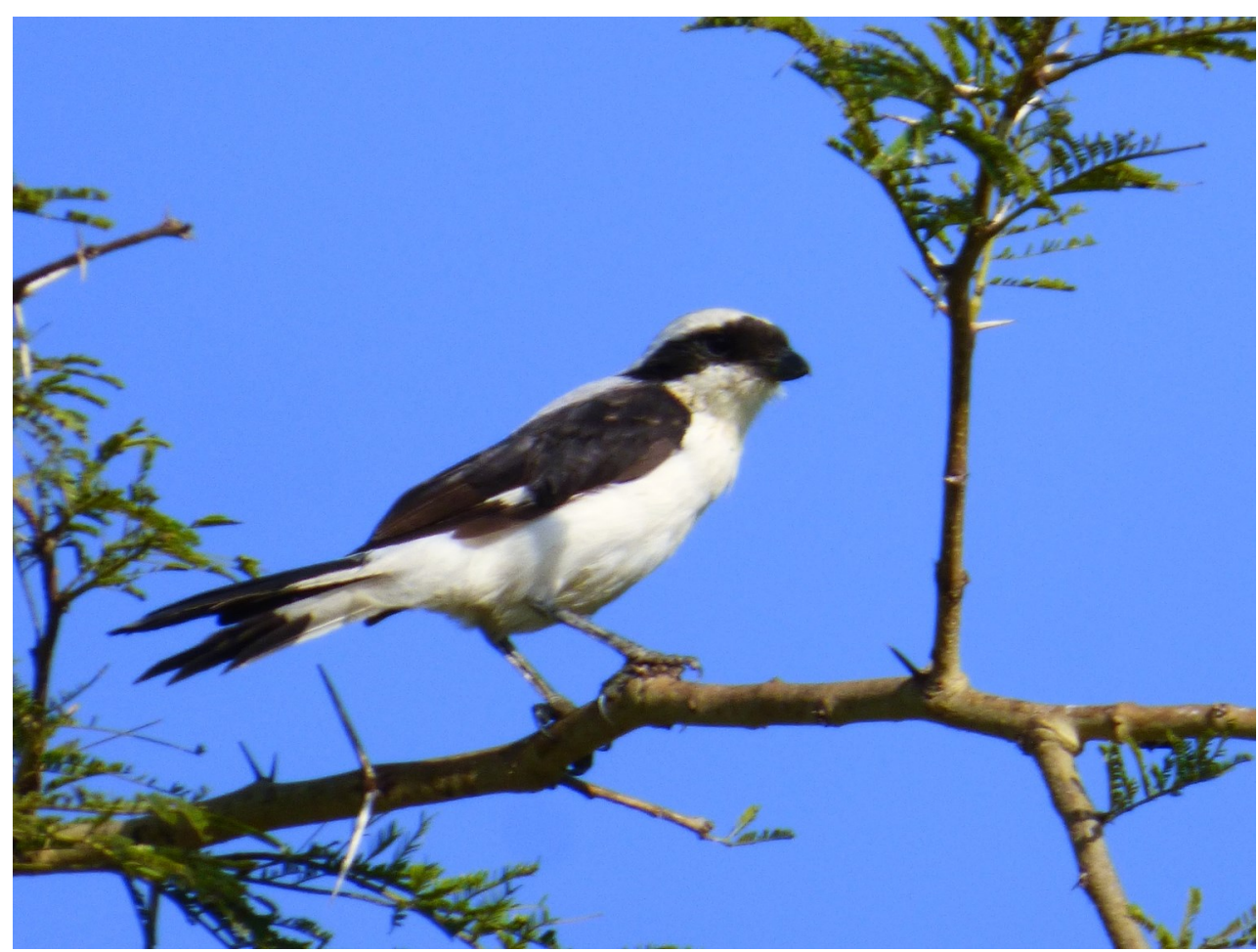

Figure 7. BirdPix record 99229, Lanius excubitoroides from Yola, Adamawa State. This record is also a range extension, submitted by the author to the BirdPix database. Further details are at http:// vmus. adu.org.za/?vm=BirdPix-99229

family level, whereas some species can readily be identified from a poor, even partially blurred photograph (Underhill et al. 2018). However, a few species can only be identified in the hand, mostly Warblers and Cisticolas. As a beginner participant, the best strategy for receiving positive confirmed identification is to submit the best photograph. The most important parts of the bird to have in sharp focus are the face and wing. There is an exceptional field guide to the Birds of Western Africa written by Nik Borrow and Ron Demey. It is published by Princeton or Helm. It describes and illustrates 1300 bird species occurring in all 23 countries of Western Africa (Borrow \& Demey 2014).

\section{What instruments do I need?}

To make a submission to the BirdPix project, you only need a smartphone or digital camera for taking photographs. Then follow the upload procedure described above. For location coordinates, you do not necessarily need a Global Positioning System (GPS) to take point coordinates, because the VM website is equipped with Google Earth and Map to help you locate the point where the species was photographed.

\section{Primary challenges facing citizen science in Nigeria}

Although citizen science has long been in existence, its development in Nigeria as in most African countries is still in its infant stage and is largely challenged by a lack of strong enthusiasm among citizens. This is mainly from lack of awareness on the importance of biomapping and conservation, but also poverty since not many citizens are willing to sacrifice their resources and time for data collection. Moreover, those with keen interest are constrained by limited access to resources and field instruments like binoculars, cameras, and transport, making it difficult to go out and report observations. On one hand, some withdraw from the project after realizing that it is an unpaid activity. Uncertainties including insecurity, kidnapping, insurgency, and banditry are also considerable challenges affecting citizen science participation across the country. This is on the grounds that citizen scientists do not have a sense of security going out to the bush for biomapping. In some cases, citizen scientists are misunderstood by security personnel and locals as informants to kidnappers or bandits because of their gear, for example, binoculars and digital cameras they carry.

\section{Conclusions and recommendations}

This paper highlights the content of the BirdPix database in Nigeria. It provides up-to-date information on the species distribution maps and lists of bird species recorded in the BirdPix project's grid cells. Without a doubt, the BirdPix database will only be comprehensive if the database contains the entire knowledge base of species occurring within each QDGC. Data generated in the BirdPix project can be used for 
Table 3. The seven globally threatened species (based on the IUCN RedList) in the BirdPix database for Nigeria as of 15 December 2019

\begin{tabular}{|c|c|c|c|c|c|}
\hline Code & $\begin{array}{c}\text { Scientific } \\
\text { name }\end{array}$ & $\begin{array}{c}\text { Common } \\
\text { name }\end{array}$ & $\begin{array}{l}\text { Red } \\
\text { List }\end{array}$ & $\mathbf{n}$ & Last recorded \\
\hline 108 & $\begin{array}{l}\text { Torgos tracheli- } \\
\text { otus }\end{array}$ & $\begin{array}{l}\text { Lappet-faced } \\
\text { Vulture }\end{array}$ & EN & 1 & 23-01-2009 \\
\hline 111 & $\begin{array}{l}\text { Neophron } \\
\text { percnopterus }\end{array}$ & $\begin{array}{l}\text { Egyptian Vul- } \\
\text { ture }\end{array}$ & EN & 1 & 07-03-2012 \\
\hline 110 & $\begin{array}{l}\text { Necrosyrtes } \\
\text { monachus }\end{array}$ & $\begin{array}{l}\text { Hooded Vul- } \\
\text { ture }\end{array}$ & CR & 5 & $13-10-2019$ \\
\hline 107 & Gyps africanus & $\begin{array}{l}\text { White-backed } \\
\text { Vulture }\end{array}$ & CR & 1 & 27-02-2007 \\
\hline 109 & $\begin{array}{l}\text { Trigonoceps oc- } \\
\text { cipitalis }\end{array}$ & $\begin{array}{l}\text { White-headed } \\
\text { Vulture }\end{array}$ & CR & 1 & 27-02-2007 \\
\hline 3894 & $\begin{array}{l}\text { Ploceus banner- } \\
\text { mani }\end{array}$ & $\begin{array}{l}\text { Bannerman's } \\
\text { Weaver }\end{array}$ & VU & 1 & $14-05-2018$ \\
\hline 151 & $\begin{array}{l}\text { Terathopius } \\
\text { ecaudatus }\end{array}$ & Bateleur & NT & 1 & 22-06-2019 \\
\hline
\end{tabular}

monitoring and modelling changes in species distribution, and composition over time (Underhill et al. 2018). Increasing local awareness of the concept of citizen science and recruiting more volunteers should be top priorities.

\section{Acknowledgements}

I dedicate this paper to the memory of Rob Dickinson, who played a vital role in assembling photographic data of African biodiversity in the Virtual Museum. I would like to appreciate all the citizen scientists for their photographs. The A.P. Leventis Ornithological Research Institute (APLORI) invited me to the first workshop on Atlasing and Monitoring in Africa in 2017, which significantly improved my knowledge about biomapping, and I am extremely grateful. Dr. Megan Loftie-Eaton and Karis Daniel proofread and provided invaluable assistance in writing this manuscript. Dr. Sam T. Ivande helped with vital information on the history of citizen science in Nigeria.

\section{References}

Borrow N, Demey R 2014. Birds of Western Africa. 2nd ed. Princeton University Press, Princeton.

Chandler M, See L, Copas K, Bonde AM, López BC, Danielsen F, Legind JK, Masinde S, Miller-Rushing AJ, Newman G, Rosemartin A, Turak E 2017. Contribution of citizen science towards international biodiversity monitoring. Biological Conservation 213: 280-294.

Donald PF, Fishpool LD, Ajagbe A, Bennun LA, Bunting G, Burfield IJ, Butchart SHM, Capellan S, Crosby MJ, Dias MP, Diaz D, Evans MI, Grimmett R, Heath M, Jones VR, Lascelles B G, Merriman JC, O'Brien M, Ramirez I, Waliczky Z, Wege DC 2019. Important Bird and Biodiversity Areas (IBAs): the development and characteristics of a global inventory of key sites for biodiversity. Bird Conservation International 29: 177-198.

Donnelly A, Crowe O, Regan E, Begley S, Caffarra A 2014. The role of citizen science in monitoring biodiversity in Ireland. International Journal of Biometeorology5 8: 1237-1249.

Dowsett RJ 2018. Nigeria Checklist. Accessed at https:// www.africanbirdclub.org/sites/default/files/15_NigeriaList_Dowsett.pdf on 20 January 2020

Kobori H, Dickinson JL, Washitani I, Sakurai R, Amano T, Komatsu N, Kitamura W, Takagawa S, Koyama K, Ogawara T, MillerRushing AJ 2016. Citizen science: a new approach to advance ecology, education, and conservation. Ecological Research 31: 1-19.

Loftie-Eaton M, Underhill LG, Navarro R 2018. OdonataMAP - Progress report on the Atlas of the Dragonflies and Damselflies of Africa 2016/17 and 2017/18. Biodiversity Observations 9.13: 1-10

Louv R, Fitzpatrick JW 2012. Citizen science: Public participation in environmental research. Cornell University Press.

Ringim AS, Ibrahim JI, Ottosson U, Ivande ST, Tende T, Ezekiel SP 2020. An extension to the known range of the Grey-backed Fiscal Lanius excubitoroides in Nigeria. Malimbus 42: 31-32. 
Ringim AS, Abu P, Ottosson U, Ivande ST, Tende T, Abubakar HM, Okwhofase J, Ezekiel SP, Muhammad SI 2019. Range extension and breeding of the House Sparrow Passer domesticus in Nigeria. Malimbus 41: 63-65.

Roberge JM, Mikusiński G, Svensson S 2008. The white-backed woodpecker: umbrella species for forest conservation planning? Biodiversity and Conservation 17: 2479-2494.

Silvertown J 2009. A new dawn for citizen science. Trends in Ecology and Evolution 24: 467-471.

Tende T, Ivande S, Ottoson U 2016. Nigeria Bird Atlas Project: How far so far? Progress report August 2016. Biodiversity Observations 7.50: 1-3.

Underhill LG, Loftie-Eaton M, Navarro R 2018. Odonata of the Kruger National Park. Biodiversity Observations 9.11: 1-16.

Wilson JM, McGregor R 2002. House sparrow Passer domesticus in NE Nigeria. Malimbus 24: 41-42.

\section{Editorial acknowledgements}

Les Underhill thanks Karis Daniel and Megan Loftie-Eaton for assistance with the production of this paper.

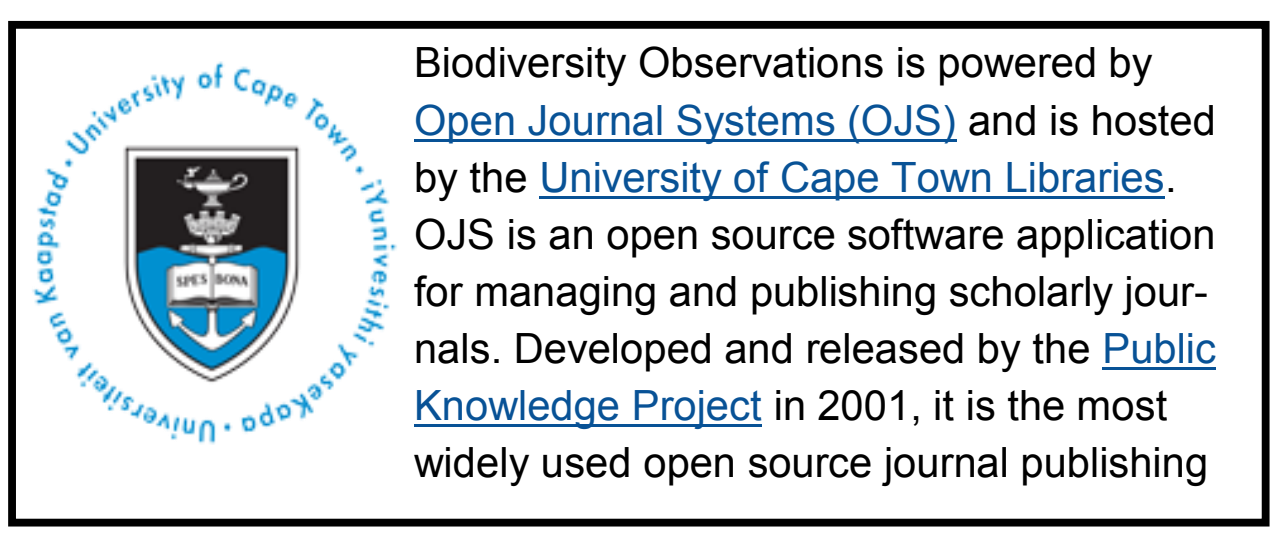

\section{Biodiversity Observations}

The scope of Biodiversity Observations includes papers describing observations about biodiversity in general, including animals, plants, algae and fungi. This includes observations of behaviour, breeding and flowering patterns, distributions and range extensions, foraging, food, movement, measurements, habitat and colouration/plumage variations. Biotic interactions such as pollination, fruit dispersal, herbivory and predation fall within the scope, as well as the use of indigenous and exotic species by humans. Observations of naturalised plants and animals will also be considered. Biodiversity Observations will also publish a variety of other interesting or relevant biodiversity material: reports of projects and conferences, annotated checklists for a site or region, specialist bibliographies, book reviews and any other appropriate material. Further details and guidelines to authors are on the journal website (https://journals.uct.ac.za/index.php/BO/).

\section{ISSN 2219-0341}

Editors: PN Laver and LG Underhill

\section{biodiversity observations}

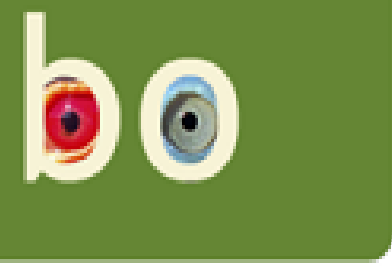

